\title{
A poesia erótica de Lucas José d'Alvarenga
}

\author{
[ The erotic poetry of Lucas José d'Alvarenga]
}

\section{Gracinéa I. Oliveira ${ }^{\mathrm{I}}$}

RESUMO - O objetivo deste artigo é analisar a poesia erótica de Lucas José d’Alvarenga. Para execução desta análise, foi feita uma pesquisa monográfica, usando a técnica de pesquisa indireta, especificamente a bibliográfica, que consistiu em breve revisão da bibliografia já publicada referente ao livro de Lucas José d’Alvarenga, Poezias (I830), objeto desta pesquisa. A seleção e a análise dos poemas foram norteadas pelo conceito de erotismo, proposto por Octavio Paz. Foram identificados I3 poemas eróticos no livro, entre improvisos, quadras, sonetos e vilancetes. $\mathrm{O}$ erotismo foi representado nesses poemas através de antíteses e de metáforas, sendo as características eróticas mais recorrentes a imaginação, a percepção do sexo como recreação e a privacidade $x$ o voyeurismo. PALAVRASCHAVE - Erotismo; poesia; Lucas José d'Alvarenga; século XIX. - ABSTRACT - The purpose of this article is to analyze the erotic poetry of Lucas José d'Alvarenga. For the execution of this analysis, a monographic research was done using the indirect research technique, specifically the bibliographical one, which consisted of a brief review of the bibliography already published concerning the work of Lucas José d'Alvarenga the book Poezias (I830) -, object of this research. The selection and analysis of the poems were guided by the concept of eroticism, proposed by Octavio Paz. Thirteen erotic poems were identified in the book, among improvisations, quatrains, sonnets and vilancetes. Eroticism was represented in these poems through antitheses and metaphors, being erotic features most recurrent the imagination, the perception of sex as recreation and privacy vs. voyeurism. - KEYWORDS - Eroticism; poetry; Lucas José d'Alvarenga; XIX century.

Recebido em 5 de junho de 2017

Aprovado em 2I de novembro de 2017

OLIVEIRA, Gracinéa I. A poesia erótica de Lucas José d’Alvarenga. Revista do Instituto de Estudos Brasileiros, Brasil, n. 68, p. I87-207, dez. 2017.

DOI: http://dx.doi.org/Io.II6o6/issn.23I6-90IX.voi68pI87-207

I Faculdade de Ciências Sociais Aplicadas de Belo Horizonte (FACISABH, Belo Horizonte, MG, Brasil). 


\section{Apresentação}

Lucas José d'Alvarenga nasceu em Sabará, em I768. Estudou Leis em Coimbra e, posteriormente, retornou às Minas, onde exerceu alguns cargos públicos na sua cidade natal, como o de promotor dos Resíduos e Cativos e o de procurador fiscal dos Defuntos e Ausentes da Provedoria Geral. Em I804, seguiu para Lisboa, na tentativa de conseguir prestar serviço nas Índias, para onde partiu como ajudante de ordens de Sarzedas, em I806. Governou Macau entre I809 e I8Io, conseguindo uma vitória espetacular, do ponto de vista militar e político, sobre piratas chineses que assolavam a região. Saiu do governo devido a divergências políticas. Após permanecer certo tempo em Goa e viajar pela Europa, retornou ao Brasil em I8I5, fixando residência no Rio de Janeiro, onde faleceu em I83I. Além do livro Poezias, escreveu uma novela - Statira, e Zorastes (I826) -, primeira do gênero publicada no Brasil, e três livros de memórias, em I828 e I830. Nesses livros relata, sobretudo, sua estadia na Ásia².

O livro Poezias foi publicado pela primeira e única vez em I830, um ano antes da morte de seu autor. Apesar disso, contém poemas feitos ao longo da vida do poeta, dos I3 aos 62 anos, como é perceptível em declarações suas em algumas notas de rodapé: "Estes versos, e os de pag. 95 forão feitos em Minas, tendo eu de idade I3 ou I4 annos, pouco mais, ou menos" 3 . Em outro poema, um improviso, ele comenta quando o compôs: "De improvizo em caza, e á meza de hum Titular desta Corte em I7 de Setembro de I829 [...]"4, ou seja, um ano antes de sua publicação. Embora contenha poemas da juventude à maturidade do escritor, trata-se do primeiro volume da obra. Entretanto não se localizaram os demais volumes. Supõe-se que Alvarenga talvez não tenha tido tempo de publicá-los, já que se encontrava bastante debilitado pela doença e pela idade à época, como ele mesmo declara em um de seus livros de Memória:

2 OLIVEIRA, Gracinéa I. Edição e estudo da novela Statira, e Zoroastes, de Lucas José d'Alvarenga. Tese (Doutorado em Literatura Brasileira). Faculdade de Letras da Universidade Federal de Minas Gerais, Belo Horizonte, 2016. Disponível em: <www.bibliotecadigital.ufmg.br/dspace/handle/I843/LETR-AHXM9W >. Acesso em: Io ago. 2017 .

3 ALVARENGA, Lucas José de. Poezias. t. I. Rio de Janeiro: Ogier, I830, p. II5.

4 Ibidem, p. 9I. 
No I ${ }^{0}$ de Fevereiro de I825 [...] Apresentei-me ali á hora dada, assim mesmo, como estava, atacado de hum typho, com huma febre ardentissima, e de que estive a morte. [...] He esta a data, em que teve principio a minha impossibilidade de continuar, como dantes, no Serviço, ou em que principiou a Epoca deste meu censurado Ocio 5 .

Não obstante ter tido apenas uma edição e seu autor ser mais lembrado como novelista e como administrador público do que como poeta, esse livro despertou o interesse de alguns críticos, sobretudo os do século XIX. Joaquim Norberto de Sousa Silva, por exemplo, tencionava reeditar a obra de Alvarenga, como afirma no prefácio da edição do livro de Laurindo Rabelo, feita por ele:

Não é minha culpa senão do público, que mal correspondeu os sacrifícios feitos pelo coletor e seu editor, pois há muito que os autores prometidos aguardam a ver de entrar para o prelo e de ocupar o seu lugar de honra em uma publicação que em qualquer país seria protegida como um monumento de glória nacional. [...] Assim Basílio da Gama, Santa Rita Durão, Antônio José, Cláudio Manuel da Costa, Marquês de Paranaguá, Marquês de Marica, Natividade Saldanha, Lucas José de Alvarenga, José Bonifácio, Lopes Gama, o Carapuceiro, $D^{a}$ Beatriz e tantos outros aí ficam no pó do esquecimento, depois de tanta pesquisa sobre suas obras e ainda sobre suas biografias, graças à indiferença da pátria ${ }^{6}$.

Como se vê, no final do século XIX a obra de Lucas José d’Alvarenga foi colocada ao lado de outras, como as de Basílio da Gama e as de Cláudio Manuel da Costa, sendo que estes últimos se consolidaram no cânone literário brasileiro. Entretanto, apesar de Joaquim Norberto não ter reeditado os livros de Alvarenga, sua obra poética não ficou em completo esquecimento.

Martins de Oliveira7, no século XX, também analisou a obra desse poeta. Para ele, Alvarenga foi um poeta romântico, precursor da vertente condoreira, a quem caberia o título de introdutor do Romantismo no Brasil. Não se concorda com essa posição do crítico, visto que, embora nos poemas de Alvarenga seja possível encontrar traços do Romantismo, ainda há influência do Arcadismo e a temática social está ausente. Mas há um aspecto da poesia de Alvarenga que chamou a atenção nesta pesquisa:

5 ALVARENGA, Lucas José de. Artigo addicional à memória. Rio de Janeiro: Typographia do Diario, I828, p. 20-2I.

6 Como não se conseguiu acesso à edição de 1876 da obra poética de Laurindo Rabelo, organizada por Joaquim Norberto, utilizou-se a citação feita por Roberto Acízelo de Souza em seu artigo. Na Biblioteca Digital da Universidade Federal de Santa Catarina, há a versão digital da edição de I876, mas sem o juízo crítico. SILVA, Joaquim Norberto de Sousa. Juízo crítico de escritores nacionais e de uma notícia sobre o autor e suas obras. In: RABELO, Laurindo José da Silva. Obras poéticas. Coligidas, anotadas, precedidas do juízo crítico de escritores nacionais e de uma notícia sobre o autor e suas obras por J. Norberto de Sousa-Silva. Rio de Janeiro: B. L. Garnier; Paris: E. Belhate, I876 apud SOUZA, Roberto Acízelo de. Joaquim Norberto e sua contribuição à edição de textos e à crítica literária. Revista de Letras, São Paulo, v. 48, n. I, p. 9-26, jan./jun. 2008, p. I5. Disponível em: 〈seer.fclar.unesp.br/letras/article/viewFile/930/798〉. Acesso em: I7 mar. 2017.

7 OLIVEIRA, Martins de. História da literatura mineira. 2 ed. Belo Horizonte: Imprensa Oficial, I963. 
o erotismo. Esse tema já havia sido notado anteriormente, por Joaquim Norberto de Sousa Silva, no texto "Bosquejo da história da poesia brasileira”, publicado em Modulações poéticas: "Lucas José de Alvarenga, de Minas Geraes, deu-se a poesia erotica e deixou-nos mui bonitas cousas, que correm impressas". Durante as muitas leituras de Poezias, percebeu-se que o erotismo é realmente recorrente, sobretudo nas composições mais próximas aos gêneros da música popular, como os improvisos. Levando isso em consideração, pretende-se, nesta pesquisa, analisar a poesia erótica nessa obra de Alvarenga.

Esta pesquisa foi motivada pelo fato de se considerar o erotismo um aspecto importante da cultura, um dos diferenciadores da sexualidade humana: “[...] o erotismo não é mera sexualidade animal - é cerimônia, representação. O erotismo é sexualidade transfigurada: metáfora" . Além disso, é um tema que perpassa a literatura ocidental da época clássica até a atualidade, já que se encontram obras literárias de viés erótico em diversas épocas. Entretanto, para Zucchi ${ }^{\mathrm{Io}}$, apesar da proliferação de obras que são perpassadas por essa temática, não há uma crítica literária preocupada com o tema. Segundo ela, "[...] a invisibilidade que a literatura erótica sofre é resultado de um mal-estar maior, em que não é apenas o 'falar sobre sexo' que está em jogo, mas um conjunto de crenças e valores sustentados há vários séculos por uma elite intelectual”ı. Isso mostra a necessidade de estudar essa temática na literatura, já que se trata de "algo" que diz respeito à própria condição humana.

A falta de pesquisas sistemáticas relativas a esse tema na literatura, sobretudo na brasileira, é outro fato que justifica esta pesquisa. Zucchi ${ }^{12}$, por exemplo, afirma que não há “uma tradição literária brasileira erótica consistente” e considera Gregório de Matos o primeiro representante dessa vertente no Brasil. Além dele, cita como representantes alguns naturalistas do final do século XIX e alguns escritores dos séculos XX e XXI. Isso demonstra realmente a falta de pesquisa sistematizada relativa ao tema, já que há, sim, uma tradição no Brasil de literatura erótica porque o erotismo é um tema que perpassa obras de escritores de diversas épocas, como Casimiro de Abreu, Álvares de Azevedo ${ }^{\text {I3 }}$, Silva Alvarenga, Tomás Antônio Gonzaga e Lucas José d'Alvarenga que, embora tenha publicado no século XIX, escrevia desde o século XVIII. Daí a necessidade de pesquisa que contemple esse tema em época

8 SILVA, Joaquim Norberto de Sousa. Modulações poéticas. Rio de Janeiro: Francesa, I84I, p. 44. Disponível em: <www.literaturabrasileira.ufsc.br/documentos/?action=midias\&id=I43556〉. Acesso em: Io out. 2015.

9 PAZ, Octavio. A dupla chama: amor e erotismo. São Paulo: Siciliano, I994, p. I2.

Io ZUCCHI, Vanessa. Do prazer do texto ao prazer da crítica. Revista Investigações, Recife, v. 27, n. I, p. I-I3, jan. 20I4. Disponível em: <periodicos.ufpe.br/revistas/INV/article/view/492〉. Acesso em: 22 mar. 2017.

II Ibidem, p. 5-6.

I2 Ibidem, p. 5 .

I3 RIBEIRO, Gisele Aparecida. O (des)velar do erotismo na "Lira dos vinte anos" de Álvares de Azevedo. Dissertação (Mestrado em Literatura e Crítica Literária). Pontifícia Universidade Católica, São Paulo, 2008. Disponível em: <sapientia.pucsp.br/handle/handle/I4857>. Acesso em: 22 mar. 2017. 
considerada, por Candido ${ }^{\mathrm{I}}$, crucial para a consolidação da literatura no Brasil: final do século XVIII e início do século XIX.

Apesar disso, não se ignora que há alguns pesquisadores que se debruçaram sobre esse tema na literatura luso-brasileira. Como exemplos, pode-se citar o trabalho de Eliane Robert Moraes ${ }^{I 5}$, que organizou uma antologia da poesia erótica brasileira, embora não apresente nenhum poema de Lucas José d'Alvarenga. Fernando Ribeiro Mello ${ }^{\mathrm{I6}}$ organizou e publicou, em I965, uma antologia da poesia portuguesa erótica e satírica dos séculos XVIII e XIX, que foi apreendida pela Polícia Internacional e de Defesa do Estado - PIDE, a polícia política portuguesa. Trinta e três anos depois, Natália Correia ${ }^{17}$ relança a coletânea, incluindo poetas do século XX.

Além desses, outros pesquisadores publicaram textos que tangenciam a temática erótica no Brasil, como Alexei Bueno ${ }^{18}$, que publicou uma antologia da poesia pornográfica, que engloba poemas de poetas dos séculos XVII a XX. Hansen e Moreira ${ }^{\text {I9 }}$ também tangenciaram o tema ao abordar a poesia cômica/satírica atribuída a Gregório de Matos e Guerra; assim como Pellegrini ${ }^{20}$, que analisou a poesia obscena de Francisco Moniz Barreto. Como se vê, apesar de serem pesquisas de ótima qualidade, são trabalhos esparsos, que indicam a necessidade de mais estudos sistemáticos nessa área.

\section{REFERENCIAL TEÓRICO-METODOLÓGICO}

Esta análise é de cunho bibliográfico, ou seja, foi feita com base na técnica de pesquisa indireta. Inicialmente, fez-se uma breve revisão da bibliografia publicada a respeito do objeto (Poezias) e do tema (erotismo) e, em seguida, foi feita a análise dos poemas. A seleção dos poemas do livro e a análise foram norteadas pelo conceito de erotismo de Octavio Paz.

Antes de se discutir o conceito de erotismo adotado por Paz ${ }^{2 \mathrm{I}}$, fez-se um breve levantamento do percurso etimológico do termo "erotismo" na língua portuguesa. Segundo Cunha ${ }^{22}$, essa palavra entrou na língua no século XIX (I88I) por influência

I4 CANDIDO, Antonio. Formação da literatura brasileira. 9 ed. Rio de Janeiro: Ouro sobre Azul, 2006. 2 v.

I5 MORAES, Eliane Robert (Org.). Antologia da poesia erótica Brasileira. Cotia: Ateliê, 2015.

I6 MELLO, Fernando Ribeiro (Org.). Poesia portuguesa erótica e satírica - séculos XVIII e XIX. Lisboa: Afrodite, 1965.

I7 CORREIA, Natália (Org.). Antologia de poesia portuguesa erótica e satírica. Lisboa: Antígona/Frenesi, I999.

I8 BUENO, Alexei (Org.). Antologia pornográfica. Rio de Janeiro: Nova Fronteira, 2004.

I9 HANSEN, João Adolfo; MOREIRA, Marcello. Para que todos entendais: poesia atribuída a Gregório de Matos e Guerra. Belo Horizonte: Autêntica, 20I3.

20 PELLEGRINI, Leônidas. Álbum da rapaziada. 279 f. Dissertação (Mestrado em Teoria e História Literária). Instituto de Estudos da Linguagem, Universidade Estadual de Campinas, 2008.

$2 I$ PAZ, Octavio, op. cit.

22 CUNHA, Antônio Geraldo da. Dicionário etimológico Nova Fronteira. 2 ed. Rio de Janeiro: Nova Fronteira, I997, p. 3II. 
do francês "érotisme". Mas, embora esse termo tenha entrado mais recentemente na língua, o adjetivo correspondente a ele - erótico - é bem mais antigo - século XVI. No dicionário de Bluteau, por exemplo, já constava seu registro: "Erôtico. Derivase do Grego Erao, Amo, Quero bem, \& Eros val o mesmo que Amor, \& Erotico quer dizer, Amoroso; \& Erotica he a doença de amor [...]”²3, assim como no dicionário de Moraes Silva, do século XIX, em que erótico está registrado como sinônimo de amatório e este definido como "concernente a amores" ${ }^{24}$. Ambos os dicionários remetem à Elegia I “O poeta Simónides...”, de Camões, para abonar esse termo na língua. Como a obra de Camões é do século XVI, conclui-se que a ocorrência dessa palavra na língua portuguesa é bem antiga. Entende-se que, nos séculos XVIII e XIX, erótico era uma qualidade do amor, e isso se relaciona à gênese da própria palavra.

Eros, de que erótico se origina, tem muitas genealogias, sendo a mais aceita a que o considera filho de Afrodite e de Hermes ${ }^{25}$. Posteriormente identificado com Cupido, deus do amor entre os romanos, a este os romanos atribuíram os aspectos e caracteres do mito helênico.

Um dos primeiros textos a trazer Eros como personagem foi o drama Psique $e$ Eros, de Apuleio ${ }^{26}$. Nesse drama mítico, Eros simboliza particularmente o desejo de gozo, e Psique personifica a alma, tentada a conhecer esse amor. História permeada por transgressão, castigo e redenção, esses se tornam os elementos constitutivos da concepção ocidental do amor. Como se percebe, Eros está intimamente relacionado ao universo amoroso, sendo o amor, ao mesmo tempo, desejo sensual (Eros) e espírito $\left(\right.$ Psique ${ }^{27}$. Por isso Paz afirma que "Não há amor sem erotismo como não há erotismo sem sexualidade. Mas a cadeia se rompe em sentido contrário [...]”²8, ou seja, ambos se "alimentam do fogo original: a sexualidade" 29.

Se "a união sexual é a repetição da hierogamia primeira, do enlace do Céu e da Terra, do qual nasceram todos os seres"30, o erotismo, para Paz ${ }^{3 \mathrm{I}}$, embora não exista sem a sexualidade, é a interrupção da função reprodutiva do ato sexual:

23 BLUTEAU, Raphael. Vocabulario portuguez e latino, aulico, anatomico, architectonico... Coimbra: Collegio das Artes da Companhia de Jesu, I7I2-I728, v. 3, p. I90 (CD-ROOM).

24 SILVA, Antonio de Moraes. Diccionario da lingua portugueza - recompilado dos vocabularios impressos ate agora, e nesta segunda edição novamente emendado e muito acrescentado, por Antonio de Moraes Silva. Lisboa: Typographia Lacerdina, I8I3, v. I, p. 73. Disponível em: <dicionarios.bbm.usp.br/pt-br/dicionario/ edicao/2>. Acesso em: Io jul. 20I4.

25 CHEVALIER, Jean; GHEERBRANT, Alain. Dicionário de símbolos: mitos, sonhos, costumes, gestos, formas, figuras, cores, números. 29 ed. Rio de Janeiro: José Olympio, 2016.

26 PAZ, Octavio, op. cit.

27 CHEVALIER, Jean; GHEERBRANT, Alain, op. cit.

28 PAZ, Octavio, op. cit, p. 97.

29 Ibidem, p. I85.

30 CHEVALIER, Jean; GHEERBRANT, Alain, op. cit., p. 376.

3I PAZ, Octavio, op. cit. 
Na sexualidade o prazer serve para a procriação; nos rituais eróticos o prazer é um fim em si mesmo ou tem finalidades diferentes da reprodução. [...] Em resumo, a metáfora sexual, por meio de suas infinitas variações, significa sempre reprodução; a metáfora erótica, indiferente à perpetuação da vida, interrompe a reprodução32.

Apesar de não se confundir com a sexualidade, nem com o amor, o erotismo se relaciona com ambos, visto que "sexo, erotismo e amor são aspectos do mesmo fenômeno, manifestações do que chamamos vida”33. Erotismo, para esse teórico, é a dimensão humana da sexualidade, aquilo que a imaginação acrescenta à natureza: "É um fenômeno que se manifesta dentro de uma sociedade e que consiste, essencialmente, em desviar ou mudar o impulso sexual reprodutor e transformá-lo numa representação" ${ }^{4}$. Sendo um fenômeno essencialmente humano, não há sociedade sem práticas eróticas, sendo uma das finalidades dessas práticas “[...] domar o sexo e inseri-lo na sociedade" 35 através de regras, ritos e tabus. Como fenômeno da cultura, o erotismo é sempre presente em qualquer sociedade e comporta inúmera diversidade: varia de acordo com o espaço e o tempo, enquanto o sexo é sempre o mesmo. Em síntese, o erotismo se diferencia da sexualidade pela interrupção da procriação, pelo número infinito de variedades e pela função de regular o sexo na sociedade, já que "o homem é o único ser vivo que não dispõe de uma regulação fisiológica e automática de sua sexualidade" ${ }^{6}$.

Mas o erotismo, como já afirmado, também está relacionado ao amor, já que ambos são a dupla chama que se alimenta do fogo original - a sexualidade ${ }^{37}$. Mas esse entrelaçamento não impede que se trace a linha tênue que diferencia esses modos de manifestação de vida. Embora ambos - amor e erotismo - sejam imaginação e representação, o amor "[...] transforma o sujeito e objeto do encontro erótico em pessoas únicas" ${ }^{38}$, enquanto o erotismo vê o outro não como sujeito, mas como objeto - corpo - através do qual o amante tenta saciar seus desejos e alcançar determinado estado. "O amor é escolha, o erotismo é aceitação"39, lembrando que, para haver escolha, é necessário que existam duas pessoas, ou melhor, dois sujeitos. Mas, se, por um lado, no erotismo o outro não tem voz, por outro, sem o erotismo o amor não existe: "Pelo corpo o amor é erotismo e assim se comunica com as forças mais vastas e ocultas da vida" ${ }^{\circ}$. E são as representações do corpo e do desejo por esse corpo, sendo este representado como sujeito ou não, que foram analisadas na poesia de Lucas José d'Alvarenga.

\footnotetext{
32 Ibidem, p. I2-I3.

33 Ibidem, p. I5.

34 Ibidem, p. 97.

35 Ibidem, p. I7.

36 Ibidem.

37 Ibidem.

38 Ibidem, p. 97.

39 Ibidem, p. 34 .

40 Ibidem, p. 185.
} 


\section{A POESIa erótica de LuCas José d’AlVAREnga}

Considerando-se que o erotismo é sexualidade humana representada, simbolizada, o que mais chama a atenção no livro Poezias é a variedade de formas sob as quais o erotismo é expresso. Foram encontrados treze poemas eróticos, entre epigramas, glosas, improvisos, sonetos e vilancetes, sendo que um desses poemas é da época da adolescência do poeta - I3 ou I4 anos, como ele mesmo declara. Nesse referido poema, um dos aspectos importantes é o voyeurismo do sujeito lírico, que se delicia em observar uma cena erótica. No título do poema, o destaque é para os corpos e para o entrelaçamento destes: "A curiosidade, ou os dois corpos, e hum so vulto"4. Dividido em cinco estrofes, todas com estribilho, o eu lírico conta, gradativamente, a visão dos amantes entrelaçados e o que podia ouvir de onde estava para retomar, no final do poema, à cena dos enamorados unidos:

Eu vi, eu vi (não he graça!)

De certo lugar occulto

Em hum corpo duas almas,

De dois corpos hum só vulto.

O caso he bom!

Quero contar;

Porem chitôm!...

Fui chegando pouco a pouco,

E ouvi, sem ser presentido,

Entre reciprocos mimos

Hum soluçar repetido.

O caso he bom!

Quero contar;

Porem chitôm!...

Appliquei mais os sentidos,

E ouvi (se bem me occorre)

Huns me-deixes de quem ama,

Hum soluçar de quem morre.

$O$ caso he bom!

Quero contar;

Porem chitôm!...

Já em ancias gaguejando,

Disse hum, vendo-me á porta:

"Vê, que lá... lá... lá vem gente!"

O outro: "que... que... que m'importa!"

O caso he bom!

Quero contar;

Porem chitôm!...

Em laços, que amor urdia,

4I ALVARENGA, Lucas, I830, op. cit, p. II4. 
Ambos prezos divisei;

O que fallavão, ouvia;

O que fazião, não sei.

O caso he bom!

Quero contar;

Porem chitôm!....2

Nesse poema, é perceptível a relação entre o mundo erótico e o da morte, lembrando que essa relação é uma das faces do erotismo, já que este significa, além de prazer, extinção ${ }^{43}$. Como se liga, ao mesmo tempo, à vida, pela sexualidade, e à morte, pela interrupção da reprodução, muitas metáforas eróticas pertencem a esses dois campos semânticos. Na terceira estrofe, isso está explícito nos versos "Huns me-deixes de quem ama,/ Hum soluçar de quem morre”, em que amar e morrer são dois universos que estão, ao mesmo tempo, interseccionados e paralelos, paradoxo evidenciado pelo paralelismo sintático e pela anáfora que unem esses versos, e pela vírgula, que os separa. Além disso, considerando-se plural a metáfora erótica, é possível perceber, nos versos citados, a variedade de significados que esses possuem e algumas antíteses, que também representam o paradoxo do universo erótico. Em "Huns me-deixes de quem ama", o que, aparentemente, é uma contradição - alguém que ama pedir ao amado que se afaste - na verdade faz parte dos jogos eróticos. Esses "me-deixes" significam justamente o contrário: “fique comigo", pela visão do eu lírico, expressa no poema.

Em relação à voz, ou melhor, ao dizer ou não dizer, ela também é um elemento de erotização que perpassa o poema, tanto na voz do sujeito lírico - que deseja contar o que viu, mas impõe como condição o silêncio ao leitor: "O caso he bom!/ Quero contar/ Porem chitôm" - quanto nas vozes dos amantes, que oscilam entre soluços e gaguejos provocados pelo desejo. O silêncio imposto ao leitor duplica a cena do poeta-voyeur, transformando o leitor no sujeito lírico, e os amantes, no poema, o que também duplica a erotização do texto, se se considera, como $\mathrm{Paz}^{44}$, a poesia como erotização da linguagem.

Considerando que o erotismo é uma "poética corporal"45, percebe-se que o corpo é o centro ao redor do qual giram os demais elementos. E os corpos são o tema principal desse poema, desde o título até o final, em que esses não estão explícitos, mas são retomados por "ambos". Os corpos unidos despertam a atenção do eu lírico, que finge, no final, não saber o que faziam, embora, anteriormente, afirme que estivessem presos "Em laços, que amor urdia”. Lembrando a multiplicidade da metáfora erótica, urdir pode significar não apenas os fios do desejo e do bem-querer que enlaçavam os amantes, mas também enredo, fantasia e imaginação, sendo esta última um dos elementos caracterizadores do erotismo: "A imaginação é o agente que move o

\footnotetext{
42 Ibidem, p. II4-II5.

43 PAZ, Octavio, op. cit.

44 Ibidem.

45 Ibidem.
} 
ato erótico e o poético"46. E esse enredamento dos amantes está indicado não só na palavra "prezos", mas também nas rimas da última quadra, já que nesta todos os versos seguem o esquema $A B A B$. Nas quadras anteriores, a rima ocorria só entre os segundos e quartos versos; ou seja, na última quadra consolida-se a união dos corpos dos amantes, lembrando que, para Paz, as rimas são "cópula de sons"47.

Esse tema de dois corpos em um só vulto aparece novamente em um soneto do poeta, feito quando ele estava em Coimbra, no primeiro ano da faculdade. Nesse, percebe-se uma posição diferente do sujeito lírico ao observar a cena:

Hum dia destes proximos passados,

Estando a noite co'o luár divina,

Encontrei junto ao Arco d'Almedina

Dois vultos n'hum só vulto combinados.

Eis de repente os vejo separados,

E oiço ao mesmo tempo em voz mui fina:

"Ora dize, porque minha menina?

Que modos esses tão arrebatados?"

Responde ella: "Em debuxos não se meta!

Nenhuma moça em Coimbra co'os amantes,

Sem prometer cazar, já cahe na pêta."

Grito, correm, conheço hum dos tratantes;

Era o Chorão da porca servilheta

Hum Garôto de certos Estudantes ${ }^{48}$.

O poema começa evocando uma bela paisagem noturna, que tem a lua como centro e motivo da beleza. A imagem do disco lunar é parcialmente duplicada no texto através do "Arco de Almedina", que faz referência à Porta de Almedina, resquício urbano da antiga muralha medieval que protegia a cidade de Coimbra 49 . Atualmente, esse arco tem a forma de um semicírculo na parte superior. A imagem da lua evoca melancolia ${ }^{50}$, a feminilidade, a vida, ou melhor, as forças fecundadoras da vida ${ }^{51}$. A ideia de unicidade, que o círculo traz, aparece no poema tanto na imagem da lua/luar, quanto na imagem dos dois corpos em um "só vulto combinados", que o eu lírico avista.

Mas essa paisagem enluarada, em que se fundem os corpos dos dois enamorados, é perturbada pela separação repentina desses amantes, provocada pela função do

46 Ibidem, p. I2.

47 Ibidem.

48 ALVARENGA, Lucas José de, I830, op. cit, p. II.

49 PATRIMÓNIO edificado com interesse cultural - Concelho de Coimbra. Coimbra, 2009. Disponível em: <http://www.patrimoniocultural.gov.pt/pt/patrimonio/patrimonio-imovel/pesquisa-do-patrimonio/ classificado-ou-em-vias-de-classificacao/geral/view/69864>. Acesso em I8 abr. 2017.

50 HANSEN, João Adolfo; MOREIRA, op. cit., p. 392.

5 I CHEVALIER, Jean; GHEERBRANT, Alain, op. cit. 
erotismo de regular o sexo na sociedade. A amada não apenas se desvencilha dos braços do amado, como impõe uma condição para atender aos desejos e aos planos dele - a promessa de casamento, argumentando ser esse o comportamento de qualquer moça da cidade.

Essa quebra de unidade é representada no poema não só pela separação do casal, mas também pela imagem do próprio arco, que é um semicírculo e, dessa maneira, simboliza a interrupção da unicidade, que inicialmente estava presente no texto na figura da lua e dos amantes entrelaçados. E essa separação torna-se ainda maior quando o sujeito lírico se intromete na cena, comportamento diferente do poema anterior. Enquanto no anterior, o poeta se compraz em observar o episódio, nesse ele grita e espanta o casal, assim que percebe o afastamento dos amantes provocado pelos protestos de um deles - da figura feminina.

Esse jogo erótico, envolvendo o medo de ser visto por alguém, aparece também em outro poema - um vilancete:

MOTE.

Se quer, que lhe queira bem,

Venha fazer para aqui

Aquillo, que lhe pedi,

$\mathrm{E}$ antes que venha alguem.

GLOZA.

TYRSE com Lilia brincava

No seu Jardim certo dia;

E entre mil coizas pedia

Huma, porque suspirava.

Lilia terna se escusava

Com pejo, medo, e desdem;

E temendo a visse alguem,

Lhe diz, meu bem, meu feitiço,

Ora não me falle nisso,

Se quer, que lhe queira bem!

Com huma instancia amoroza

Tyrse os rogos repetia;

E Lilia já respondia

Entre risonha e chorosa:

Se eu não fosse tão medroza,

Tudo faria por ti.

Tyrse já fóra de si,

Diz, meu bem, não recceêmos!

Que bella sombra aqui temos!

Venha fazer para aqui.

Continûa Tyrse a instar,

Pela mão a vai levando;

Ella, hum pouco repugnando,

Se vai deixando levar. 
Que accomodádo lugar,

Diz elle, achamos aqui!

Mais occulto inda o não vi:

Diga-me se póde haver

Mais proprio para fazer

Aquillo, que lhe pedi?

Lilia no laço amoroso

Com Tyrse cahir se deixa;

Ella chóra, elle se queixa;

Mas por fim se ergue ditoso.

Com semblante vergonhoso,

Mas já sem medo, e desdem

Diz Lilia “Tyrse, meu bem!

Se quer mais disso, que fez,

Ande depressa outra vez,

$E$ antes, que venha alguem ${ }^{52}$.

Nesse vilancete, ao invés de as ideias do mote serem glosadas em oitavas, como geralmente era feito, elas o foram em décimas espinelas, sendo os últimos versos de cada décima um dos versos do mote. Neste, alguém coloca como condição para que queira bem ao outro que este faça algo que lhe foi pedido antes que aparecesse outra pessoa. O que foi pedido não é explicitado, apenas referenciado pelo demonstrativo "aquilo", que, por sinal, é extremamente genérico. Entretanto, a condição de não poder ser visto aponta para algo que ou era censurado pela sociedade ou exigia privacidade. Além disso, ao não se dizer o que foi solicitado, atiça-se a curiosidade e a imaginação do leitor, sendo esta última, segundo $\mathrm{Paz}^{53}$, um dos agentes de transformação do erotismo, a sua força motriz.

Na glosa, esse assunto é desenvolvido em um cenário idílico - um jardim - e a ideia do jogo erótico é apontada já no início pelo verbo "brincar", visto que Tirse e Lília brincavam nesse local. Nas quadras das três primeiras décimas, o foco é em Tirse e nos pedidos dele a Lília. Já na quadra da última décima, o foco é nos amantes e no ato sexual. Nas sextilhas, o tema é desenvolvido de forma diferente: na primeira décima, a ênfase é dada à reação de Lília ao pedido do namorado; na sextilha da segunda décima, são apresentados os argumentos dos dois enamorados e, na sextilha da terceira, a atenção é voltada à reação de Lília após a concretização do ato sexual.

O jogo erótico, nesse texto, é construído entre o dito, o não dito e o medo de ser visto. Começando em uma paisagem bucólica, associada ao frescor, à sombra e ao refúgio, e em um clima de descontração, as personagens dizem o que querem, mas não nomeiam o referente, apenas se referem a ele através de retomadas anafóricas de algo que havia sido colocado fora das vistas do leitor: "E entre mil coizas pedia/ Huma, porque suspirava. [...] Ora não me falle nisso" ${ }^{4}$. Lília também desejava o que Tirse lhe

52 ALVARENGA, Lucas José de, I830, op. cit., p. 23-24.

53 PAZ, Octavio, op. cit.

54 ALVARENGA, Lucas José de, I830, op. cit., p. 23 (grifos nossos). 
pedia: “Lilia terna se escusava", mas rejeitou, inicialmente, o pedido por medo de que alguém visse o que iriam fazer: "E temendo a visse alguem"55. Ao perceber que Lília também queria o que ele tanto almejava, Tirse é transtornado pelo desejo e, em lugar de suspiros queixosos, fica fora de si e indica a ela um lugar sombreado, que julga adequado para que fizessem o que ambos muito queriam.

É interessante notar a mudança gradativa no comportamento das personagens, provocada pela chama erótica: no início Tirse faz o pedido entre suspiros e queixas, mas no decorrer do tempo vai se tornando mais enfático até mudar das palavras à ação, ao levar Lília pela mão ao lugar escolhido. Lília, por outro lado, inicialmente rejeita, embora de forma terna, as solicitações dele, demonstrando vergonha, medo e um pouco de altivez. Entretanto, à medida que ele apontava solução, sobretudo para o medo dela, ela muda de atitude e passa a rejeitar as investidas entre risos e queixas, colocando a culpa da recusa no medo. No fim, ela cede ao se deixar levar por ele e ao lhe solicitar que façam sexo novamente.

$\mathrm{O}$ ato sexual não é posto explicitamente no poema, é sempre sugerido nas sombras das elipses, como o lugar escolhido pelos amantes: oculto e sombreado. Assim como Psique, Lília não suporta o brilho de Eros: para conhecê-lo ela precisa de, pelo menos, uma escuridão parcial. Além das elipses e da imprecisão semântica dos demonstrativos, o erotismo aparece na ambiguidade da quadra da última décima, em que Lília cai nos braços de Eros ao se deitar com Tirse: "Lilia no laço amoroso/ Com Tyrse cahir se deixa; Ella chóra, elle se queixa; Mas por fim se ergue ditoso"56. Percebe-se que o "cair" refere-se, também, ao fato de os dois amantes se deitarem quando, no último verso dessa quadra, é dito que Tirse se levanta contente. Em síntese, nesse poema, o erotismo coloca o sexo no campo da recreação, das brincadeiras, afastando-o, e muito, de sua função primordial - a reprodução, a manutenção da vida. Nesse campo de divertimento e de prazer, não conta apenas o ato sexual em si, mas, sobretudo, o jogo que o antecede cuja regra é premiar todos os envolvidos.

O jogo entre o dito e o não dito também ocorre em outro poema, que segue transcrito:

Sei dos teus novos amores

Tudo timtim por timtim;

Dizes, que tal... e que não;

Eu sei, que tal... e que sim.

Sei que déste aos teus amores

Hum raminho de Jasmim;

E que apertando-lhe a mão,

Tu lhe disseste, que sim.

Este sim, que tu lhe déste,

Deve ser para algum fim:

Julga-lo eu máo!... Isso não:

Que elle he bem bom!!... Isso sim ${ }^{57}$.

55 Ibidem, p. 23.

56 Ibidem, p. 24 (grifos nossos).

57 Ibidem, p. 67. 
O tema, como é perceptível, é a inconstância das relações eróticas. Através de um jogo entre o "sim" e o "não", o eu lírico afirma saber que sua amada tem novos amores e que, embora ela negue, ele sabe que ela gosta de outro. O símbolo dessa instabilidade é uma flor ${ }^{58}$ - o jasmim - que a interlocutora do poeta deu para seu novo amor. Mas ele não a julga mal pela sua volubilidade, muito pelo contrário, diz que as ações decorrentes desse comportamento são muito boas. Ele não explicita, assim como no poema anterior, a que proposta ela disse sim, mas é justamente o não dito, seguido das reticências, que leva o leitor a imaginar ser essa proposta relacionada ao universo sexual, tornando, dessa maneira, erótico esse poema.

Se, nesse poema, o poeta brinca com as oposições "sim" e "não", nos epigramas seguintes ele também explora o jogo entre opostos:

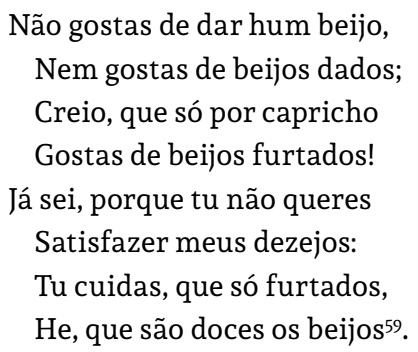

Ao contrário dos últimos poemas, nesses o eu lírico explicita o que deseja: beijos. A aparente recusa da amada em atender seu pedido é entendida como um capricho, no qual está em jogo não a vontade ou não vontade dela de beijá-lo, mas a forma como ela quer esses beijos. A ambiguidade dessa falsa recusa é expressa através dos opostos "dar/dados" e "furtados". Em síntese, ele afirma que ela quer beijá-lo, mas não quer lhe dar os beijos. O que ela deseja é que o eu lírico os tome por julgá-los, dessa maneira, mais prazerosos. O erotismo, nesse poema, expressa o desejo e o jogo de conquista entre os protagonistas do ato erótico.

Mas o erotismo não se resume apenas a esse jogo de conquista; ele é também, para $\mathrm{Paz}$, "Felicidade solar: o mundo sorri. [...] O tempo de um suspiro: uma eternidade" É a possibilidade de regresso à inocência primordial. Para ele, "O além erótico está aqui e é agora mesmo. Todas as mulheres e todos os homens viveram esses momentos: é nossa ração de paraíso"б, como se percebe na quadra abaixo:

58 CHEVALIER, Jean; GHEERBRANT, Alain, op. cit.

59 ALVARENGA, Lucas José de, I830, op. cit., p. 56-57.

6o PAZ, Octavio, op. cit., p. 28.

6I Ibidem. 
He feliz, quem chega a ver-te;

Mais feliz, quem te fallar;

Quem te beijar He mais, que homem,

He hum Deos, se te gozar ${ }^{62}$.

Nessa quadra, os sentidos são usados para demonstrar o aumento gradativo do prazer erótico junto ao corpo desejado: ver, falar, beijar e gozar estão relacionados, diretamente, à alegria, à felicidade, a ser mais que um homem e, por fim, a ser Deus. Quanto mais próximo o corpo da mulher desejada está do eu lírico, mais aumenta sua sensação de prazer: tocá-lo, através de um beijo, fá-lo mais que um homem, e gozá-lo o torna um Deus. Ser Deus nesse instante é provar da "ração do paraíso" da qual fala Octavio Paz.

Outro ingrediente erótico que aparece na poesia de Alvarenga é a imaginação, recurso que o eu lírico usa para gozar antecipadamente o corpo da mulher desejada e para convencê-la a permitir que ele a desfrute fisicamente:

MOTE.

No regaço da Ventura

Eu por sonhos me vi já.

GLOZA.

I

Meigo sonho me figura,

Quanto pede o meu dezejo;

Por meigo sonho me vejo

No regaço da Ventura.

Minha mesma boca impura

A tua tocando está;

Provo a doçura, que ha

No Cofre, que o pejo esconde;

E torno, Marilia, aonde

Eu por sonhos me vi já.

2

Eu zombo da desventura,

Pois que assim unido a ti

Já hum momento me vi

No regaço da Ventura.

Com que carinho, e brandura

Então me abraçavas lá!

Se na verdade não ha,

Meu bem, este bem suposto;

Ao menos em tanto gosto

Eu por sonhos me vi já.

62 ALVARENGA, Lucas José de, I830, op. cit., p. 70. 
O gosto sabe á loucura;

Nem eu sei mesmo, o que sou,

Quando chego, quando estou

No regaço da ventura.

Hum prazer, que pouco dura,

Mas que sempre lembrará,

Faz, que a minha alma então vá

Com a tua misturando

Doce prazer, que gozando

Eu por sonhos me vi já.

4

Não meu bem, não he loucura;

Nem ha, que contradizer-me;

Ver-me em teus braços, he ver-me

No regaço da Ventura.

O bem, que esta alma procura

Neste bem sómente está;

Mais, que dezejar, não ha;

Nem pedir mais me convem,

Visto que em tão grande bem

Eu por sonhos me vi já.

5

Mas faze verdade pura,

Faze estes sonhos reaes:

E que sê vejão os mais

No regaço da Ventura!

Premêa a minha ternura,

Que bastantes provas dá;

Faze, que eu deveras vá

Ao bem, que o pejo me esconde:

E torne realmente aonde,

Eu por sonhos me vi jáas.

Nesse poema, uma variação do vilancete, o mote é glosado em cinco décimas em que o primeiro verso do mote corresponde ao último de cada quadra, e o último verso do mote, ao último de cada sextilha. O sonho, nesse texto, é conduzido pelo desejo do eu lírico de desfrutar a amada, fato que é expresso por ele em "No regaço da Ventura", que até então lhe foi permitido apenas pela via da imaginação, um dos itens que diferencia "a sexualidade animal do erotismo humano: neste, um ou mais participantes podem ser um ente imaginário" 64 . Nesse caso, um dos protagonistas é, ao mesmo tempo, "real" e imaginário - Marília - a desejada do poeta.

63 Ibidem, p. 73-75.

64 PAZ, Octavio, op. cit., p. I6. 
Na primeira décima, o eu lírico, através de sonhos provocados por seus desejos, prova os doces beijos da amada. A imagem que chama a atenção nessa estrofe é a do cofre, cujo simbolismo tem por base dois elementos: "o fato de nele se depositar um Tesouro material ou espiritual; e o fato de que a abertura do cofre seja o equivalente a uma revelação" ${ }^{\prime 6}$. Esse cofre tem um tesouro que é escondido pelo pejo, cujo conteúdo não é explicitado no poema, mas apenas sugerido.

$\mathrm{Na}$ segunda décima, o eu lírico se regozija de já ter zombado da desventura por poder, mesmo que em sonhos, unir-se em abraços a Marília. Na terceira décima, a fusão entre os dois amantes ainda é maior, já que não apenas os corpos se uniram, mas, também, as almas deles. Embora seja rápido o gozo, esse é inesquecível, o que faz retomar a imagem de Octavio Paz de que o gozo é a "ração do paraíso"66 da humanidade, apesar de durar apenas alguns instantes. Nesse caso, o poder que a imaginação tem no erotismo é demonstrado, já que tudo isso são sonhos, devaneios do eu lírico.

Na quarta décima, ele se dirige a Marília, afirmando que tal sonho não é loucura, já que estar nos braços dela é o único bem que ele deseja. Na quinta décima, ele encerra o poema, fazendo dos sonhos argumentos para convencer sua amada a transformá-los em realidade, afirmando que ela pode premiar a ternura com a qual ele a trata, permitindo-lhe gozá-la na "realidade", fazendo com que ele fosse "Ao bem, que o pejo [...] esconde". Nesse verso, o cofre é substituído pelo seu conteúdo, ou seja, pelo tesouro que o pudor da moça a impede de revelar a ele.

Outro tema relacionado ao erotismo é a respiração, que aparece em três improvisos de Lucas José d'Alvarenga. Relacionada à vida, diversas tradições conservam o ritmo binário da respiração: a inspiração e a expiração ${ }^{67}$, que na poesia de Alvarenga vai marcar o grau da paixão entre os amantes, como no "Improviso" da página 34:

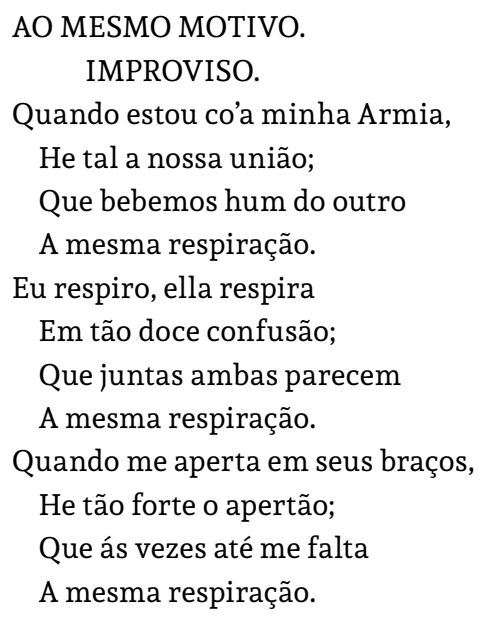

65 CHEVALIER, Jean; GHEERBRANT, Alain, op. cit., p. 262.

66 PAZ, Octavio, op. cit., p. 28.

67 CHEVALIER, Jean; GHEERBRANT, Alain, op. cit., p. 262. 
Unindo o rosto á meu rosto,

O seu ao meu Coração,

Perde os sentidos, e perde

A mesma respiração.

Eu tambem perco os sentidos,

Nem me bate o Coração;

Faltão-me os pulsos, e falta-me

A mesma respiração.

Torno á mim, e pouco á pouco

Vai batendo o Coração;

E vem, vindo de vagar

A mesma respiração.

Recobro novos alentos;

Cheio de gosto inda então

Interrompo com suspiros

A mesma respiração.

Sinto, que electrico fogo

Nos abraza o Coração;

E que á nós ambos anima

A mesma respiração.

Sei, que existe em nossas almas

O mesmo gráo de paixão;

Porque o mostra entre delírios

A mesma respiração.

Quando estou co'a minha Armia,

Estou sempre nesta acção;

Ou perdendo, ou recobrando

A mesma respiração.

Só de pintar os seus mimos

Na minha imaginação;

Tremo, emmudeço, e me falta

A mesma respiração ${ }^{68}$.

Nesse poema, a fusão dos amantes é demonstrada pela respiração deles. Assim como o mundo do sexo, ao qual o erotismo está ligado, a respiração também está relacionada diretamente aos impulsos vitais. Essa fusão é demonstrada pelo fato de o casal não apenas respirar junto, na mesma sintonia, mas por um "beber" a respiração do outro, o que mostra que os amantes estão tão unidos que aparentam ser apenas um corpo. A união sexual, sugerida no poema, pelos abraços e pela união dos corpos (rosto e coração) culmina no gozo e na suspensão temporária dos sentidos, o que é demonstrado pela perda momentânea da respiração, que o eu lírico recupera aos poucos. Mas isso não apaga a chama do desejo - "electrico fogo" -, que abrasa o

68 ALVARENGA, Lucas José de, I830, op. cit., p. 34-36. 
coração dos amantes, quando estão juntos. O ritmo binário da respiração é estendido ao gozo dos enamorados, metaforizado na imagem da perda e do recobrar da respiração. Esse ir e voltar também é expresso no poema pela repetição do motivo "A mesma respiração" no último verso de cada quadra. Além disso, a perda momentânea dos sentidos e da respiração também une o mundo do erotismo ao mundo da morte, relação já enfatizada por $\mathrm{Paz}^{69}$ e que, nesse poema, está sutilmente colocada.

\section{Conclusão}

Pelo exposto, percebe-se que muitas características do erotismo, propostas por Paz $\mathrm{Z}^{70}$ em A dupla chama, aparecem na poesia de Lucas José d'Alvarenga. Essas características são colocadas, sobretudo, através de antíteses, de imagens e de metáforas que permeiam os poemas desse autor. Entre as mais recorrentes nos textos analisados, percebe-se que a imaginação, o sexo como recreação, a privacidade $x$ voyeurismo foram as características mais frequentes nos poemas anteriormente estudados. A amada aparece, quase sempre, como objeto de prazer, nem sempre exclusivo e nem sempre fiel, mas nem por isso condenada, já que o prazer justificaria sua volubilidade.

O jogo de sedução é também um aspecto que chama a atenção na poesia de Alvarenga. Nesse, o encontro entre os amantes é apresentado, na maioria das vezes, pela voz de um dos protagonistas e, em alguns casos - em dois poemas -, por alguém que não é protagonista do ato erótico, mas um terceiro, que ora observa e partilha do prazer pela observação, ora espanta os amantes.

O cenário desses jogos varia desde o urbano até o da natureza domesticada - o jardim -, local que aparece como refúgio onde é possível manter a privacidade, ao contrário do ambiente urbano, em que muitas vezes os amantes são surpreendidos por terceiros.

Diversas imagens relacionadas ao universo erótico aparecem nos poemas, como a do fogo, a do laço, a da lua e a da respiração, todas diretamente relacionadas ao corpo, principal protagonista do ato erótico. Além disso, após a análise, pode-se afirmar que esse livro de Lucas José d'Alvarenga - Poezias - mostra que há, sim, na literatura brasileira, em período anterior ao século XX, poesia erótica à espera de estudo crítico. Isso, como afirmado no início deste artigo, vem desde as primeiras manifestações literárias, com a poesia de Gregório de Matos, e perpassa todo o século XVIII e início do XIX, ganhando visibilidade a partir dos românticos. Mas isso não diminui a importância da produção poética anterior a essa época, apenas mostra a importância de estudos dessas obras para melhor compreensão da expressão do erotismo na poesia brasileira.

69 PAZ, Octavio, op. cit.

70 Ibidem. 
GRACINÉA I. OLIVEIRA é doutora em Literatura Brasileira pela Faculdade de Letras da Universidade Federal de Minas Gerais (Fale/UFMG), professora e coordenadora do curso de Letras da Faculdade de Ciências Sociais Aplicadas de Belo Horizonte (FACISABH).

E-mail: gracineaoliveira@hotmail.com

\section{REFERÊNCIAS BIBLIOGRÁFICAS}

ALVARENGA, Lucas José de. Artigo addicional à memória. Rio de Janeiro: Typographia do Diario, I828. . Poezias. Rio de Janeiro: Ogier, I830a.I t.

BLUTEAU, Raphael. Vocabulário portuguez e latino, aulico, anatomico, architectonico... Coimbra: Collegio das Artes da Companhia de Jesu, I7I2-I728. 8 v. (CD-ROM).

BUENO, Alexei (Org.). Antologia pornográfica. Rio de Janeiro: Nova Fronteira, 2004.

CANDIDO, Antonio. Formação da literatura brasileira. 9 ed. Rio de Janeiro: Ouro sobre Azul, 2006. 2 v. CHEVALIER, Jean; GHEERBRANT, Alain. Dicionário de símbolos: mitos, sonhos, costumes, gestos, formas, figuras, cores, números. 29 ed. Rio de Janeiro: José Olympio, 2016.

CORREIA, Natália (Org.). Antologia de poesia portuguesa erótica e satírica. Lisboa: Antígona/Frenesi, I999. CUNHA, Antônio Geraldo da. Dicionário etimológico Nova Fronteira. 2 ed. Rio de Janeiro: Nova Fronteira, I997.

HANSEN, João Adolfo; MOREIRA, Marcello. Para que todos entendais: poesia atribuída a Gregório de Matos e Guerra. v. 5. Belo Horizonte: Autêntica, 2013.

MELLO, Fernando Ribeiro (Org.). Poesia portuguesa erótica e satírica - séculos XVIII e XIX. Lisboa: Afrodite, I965.

MORAES, Eliane Robert (Org.). Antologia da poesia erótica Brasileira. Cotia: Ateliê, 2015.

OLIVEIRA, Gracinéa I. Edição e estudo da novela Statira, e Zoroastes, de Lucas José d'Alvarenga. 457 f. Tese (Doutorado em Literatura Brasileira). Faculdade de Letras da Universidade Federal de Minas Gerais, Belo Horizonte, 20I6. Disponível em: <http://www.bibliotecadigital.ufmg.br/dspace/handle/I843/ LETR-AHXM9W >. Acesso em: Io ago. 2017.

OLIVEIRA, Martins de. História da literatura mineira. 2. ed. Belo Horizonte: Imprensa Oficial, I963.

PATRIMÓNIO edificado com interesse cultural - Concelho de Coimbra. Coimbra, 2009. Disponível em: $<$ patrimoniocultural.gov.pt/pt/patrimonio/patrimonio-imovel/pesquisa-do-patrimonio/classificado -ou-em-vias-de-classificacao/geral/view/69864>. Acesso em: I8 abr. 2017.

PAZ, Octavio. A dupla chama: amor e erotismo. São Paulo: Siciliano, I994.

PELLEGRINI, Leônidas. Álbum da rapaziada. 279 f. Dissertação (Mestrado em Teoria e História Literária). Instituto de Estudos da Linguagem, Universidade Estadual de Campinas, Campinas, 2008.

RIBEIRO, Gisele Aparecida. O (des)velar do erotismo na "Lira dos vinte anos" de Álvares de Azevedo. Dissertação (Mestrado em Literatura e Crítica Literária). Pontifícia Universidade Católica de São, São Paulo, 2008. Disponível em: 〈sapientia.pucsp.br/handle/handle/I4857>. Acesso em: 22 mar. 2017. 
SILVA, Joaquim Norberto de Sousa. Modulações poéticas. Rio de Janeiro: Francesa, I84I. Disponível em: <literaturabrasileira.ufsc.br/documentos/?action=download\&id=36265〉. Acesso em: Io out. 2015.

SILVA, Antonio de Moraes. Diccionario da lingua portugueza - recompilado dos vocabularios impressos ate agora, e nesta segunda edição novamente emendado e muito acrescentado, por Antonio de Moraes Silva. Lisboa: Typographia Lacerdina, I8I3. Disponível em: <dicionarios.bbm.usp.br/pt-br/dicionario/ edicao/2>. Acesso em: Io jul. 20I4.

SOUZA, Roberto Acízelo de. Joaquim Norberto e sua contribuição à edição de textos e à crítica literária. Revista de Letras, São Paulo, v. 48, n. I, p. 9-26, jan./jun. 2008. Disponível em: <seer.fclar.unesp.br/ letras/article/viewFile/930/798>. Acesso em: I7 mar. 2017.

ZUCCHI, Vanessa. Do prazer do texto ao prazer da crítica. Revista investigações, Recife, PE, v. 27, n. I, p. I-I3, jan, 20I4. Disponível em: <periodicos.ufpe.br/revistas/INV/article/view/492〉. Acesso em: 22 mar. 20I7. 